Тульчинська С.O.

доктор економ. наук, доиент

Національній технічний університет Украӥни «КПІ»

\title{
ІНТЕГРАЦІЙНА КОНЦЕПЦІЯ ФОРМУВАННЯ РЕГІОНАЛЬНИХ ЕКОНОМІЧНИХ СИСТЕМ ІНТЕЛЕКТУАЛЬНО-ІННОВАЦІЙНОГО ТИПУ В УКРАЇНI
}

\author{
ИНТЕГРАЦИОННАЯ КОНЦЕПЦИЯ ФОРМИРОВАНИЯ РЕГИОНАЛЬНЫХ \\ ЭКОНОМИЧЕСКИХ СИСТЕМ ИНТЕЛЛЕКТУАЛЬНО-ИННОВАЦИОННОГО ТИПА
}

\section{THE INTEGRATION CONCEPT OF FORMING THE REGIONAL ECONOMIC SYSTEMS INTELLECTUAL AND INNOVATIVE TYPE IN UKRAINE}

У статті розглядається інтелектуально-інновачійна система регіонів, як сукупність взаємопов'язаних, локалізованих на певній території підсистем (формування, генерачії, освоєння знань $i$ дифузї інновачій), органів регіонального управління та інститутів, які зумовлюють активізацію інновачійного процесу та забезпечують безперервно повторювальні процеси створення, нарощення та розвитку інтелектуального потенціалу регіонів. Визначені переваги регіонального рівня інноваційних процесів в порівнянні з національним. Обгрунтовано доцільність впровадження нової форми просторового територіального розвитку продуктивних сил і регіональної економіки - форму взаємодї̈ організачійно-економічного розвитку інтелектуально-інноваційної системи регіонів та ї̈ підсистем. Розроблено інтеграційну концепцію формування ресурсно-функціонального потенціалу регіонів. Головною метою запропонованої конщепиї $\epsilon$ забезпечення високого рівня ефективності розвитку інтелектуально-інноваційної системи регіонів та ї̈ підсистем на основі використання інтелектуального капіталу. Визначені основні засади концепщіï, щуо пропонується до використання - ие реалізаџія процесів формування, генераџї, освоєння знань та дифузї інновацій, забезпечення ефективності розвитку інтелектуальноінновачійної системи регіонів в умовах інтеграційного вибору держави, щуо надасть можливість становленню економіки знань.

Ключові слова: регіон, стратегія, концепція, інноваційний процес, інтелектуальноінноваційна система регіонів, інтеграційна концепція формування ресурснофункціонального потенціалу регіонів

В статье рассматривается интеллектуально-инновационная система регионов как совокупность взаимосвязанных, локализованных на определенной территории подсистем (формирования, генеращии, освоения знаний и диффузии инновачий), органов регионального управления и институтов, которые подразумевают активизацию инновационного процесса и обеспечивают непрерывно повторяющиеся процессы создания, наращивания и развития интеллектуального потенциила регионов. Определены преимущества регионального уровня инновачионных процессов по отношению к национальному. Обоснована целесообразность внедрения новой формы пространственного территориального развития производительных сил и региональной экономики - форму взаимодействия организационно-экономического развития интеллектуально-инновационной системы регионов и ее подсистем. Разработано интеграционную конщепциию формирования ресурсно-функционального потенциала регионов. Главной иелью предложенной концепции является обеспечение высокого уровня эффективности развития интеллектуально-инновационной системь регионов и ее подсистем на основе использования интеллектуального капитала. Определены основные принциипы предлагаемой конщепции - это реализаџия процессов формирования, генераџии, 
освоения знаний $и$ диффузии инноваций, обеспечения эффективности развития интеллектуально-инновачионной системы регионов в условиях интеграчионного выбора государства, что способствует становлению экономики знаний.

Ключевые слова: регион, стратегия, концепция, инновационный процесс, интеллектуально-инновационная система регионов, интеграционная концепция формирования ресурсно-функционального потенциала регионов

The article is considered the intellectual innovation system of regions as a set of subsystems, which interrelated and localized in a particular area (formation, generation, development of knowledge and innovation diffusion).

Also it is considered the regional governance and institutions that lead to activation of the innovation process for providing continuous repetitive processes of creation, accumulation and development of intellectual potential. The advantages of regional innovation processes compared to national. The introducing new form of regional space development the productive forces and regional economy - a form of interaction between organizational and economic development intellectual and regional innovation system and its subsystems is explained. The concept of resource integration and functional potential is developed. The main purpose of the proposed concept is to provide a high level of efficiency in the intellectual and regional innovation system and its subsystems through the using of intellectual capital. The basic principles, which proposed for using concept it is implementation of the formation, generation, knowledge development and diffusion of innovations. Also it is ensuring the effectiveness of intellectual innovation system regions under state integration select, which will enable the establishment of a knowledge economy.

Keywords: region, strategy, concept, the process of innovation, the intellectual and innovative system of regions, the integration concept of the resource-functional potential the regions

Вступ. Особливостями сучасних інноваційних процесів є значна кількість обслуговуючих їх спеціалізованих секторів економіки та зростаюча складність взаємодії між ними 3 метою більш повного використання потенційних можливостей. Залежно від складності і масштабів інноваційних процесів для їх реалізації можуть залучатися від одиниць до сотень організацій, в результаті чого формується розгалужена інфраструктура. Вона має складний характер як вертикально структурованої системи (виробниче підприємство, галузеві i регіональні підсистеми, які детермінуються інтелектуально-інноваційною системою регіонів), так i горизонтально структурованої системи (самоорганізації, асоціації, партнерства). Сутністю інноваційного процесу в економічній сфері $\epsilon$ створення i поширення нововведень у виробництві, інтеграція наукового потенціалу та матеріальної складової.

На наш погляд, інтелектуально-інноваційна система регіонів являє собою сприятливе середовище для інтелектуального капіталу, адже в іiі рамках органічно поєднуються усі складові частини інноваційного процесу.

Серед науковців, які приділяють значну увагу питанням інноваційного розвитку регіональної економіки необхідно відзначити О. Амошу [1], П. Бубенка [4], 3. Варналія [10], В. Василенка [5], 3. Герасимчук [7], Б. Данилишина, М. Долішнього, С. Злупка, Б. Кваснюка, М. Козоріз [16], Ю. Макогона, В. Мельника, О. Осауленка, В. Пилу, В.Поліщука, В. Семиноженко [16], Т. Смовженко, В. Соловйова [12], М. Тимчука, М. Чумаченка та ін. Як наслідок, за останні роки із проблематики стратегії 
регіонального розвитку з'явилися праці, підготовлені як колективами авторів $[2 ; 3 ; 6 ; 8 ; 10 ; 15]$, так і окремими дослідниками $[4 ; 5 ; 9 ; 11 ; 17]$.

Але незважаючи на велику кількість публікацій, присвячених регіональним проблемам інноваційного розвитку, підходи до стратегії інноваційного розвитку регіонів потребують подальшого дослідження, у тому числі за рахунок розвитку інтелектуально-інноваційної системи регіонів.

Вказані обставини обумовлюють необхідність поглиблення вивчення даного напряму дослідження, особливо за рахунок розроблення концепції формування ресурсно-функціонального потенціалу регіонів.

Постановка завдання. Метою даної статті $\epsilon$ дослідження існуючих підходів до визначення вектора розвитку постіндустріального суспільства, а саме економіки знань, з’ясування головних тенденцій iіi становлення на сучасному етапі розвитку суспільства, а також складових, які мають забезпечити процес формування та використання знання як ресурсу для розвитку регіонів та держави. Для досягнення даної мети поставлені наступні завдання:

- розглянути інтелектуально-інноваційну систему регіонів, як сукупність взаємопов’язаних, локалізованих на певній території підсистем;

- визначити переваги регіонального рівня інноваційних процесів в порівнянні з національним;

- обгрунтувати доцільність впровадження нової форми просторового територіального розвитку продуктивних сил і регіональної економіки - форму взаємодії організаційно-економічного розвитку інтелектуально-інноваційної системи регіонів та їі підсистем;

- розробити інтеграційну концепцію формування ресурснофункціонального потенціалу регіонів.

Методологія. У процесі дослідження було використано системний підхід, за допомогою якого було обгрунтовано доцільність розроблення інтеграційної концепції формування ресурсно-функціонального потенціалу регіонів, графічний метод за яким побудовано загальну блок-схему реалізації інтеграційної концепції, метод порівняння для визначення переваг регіонального рівня інноваційних процесів в порівнянні 3 національним, а також метод аналогій, наукової абстракції, аналізу та синтезу, логічний метод та ін.

Результати дослідження. На наш погляд ступінь обгрунтованості інтелектуально-інноваційної системи регіонів (IICP) є одним із визначальних положень, що обумовлюють регіональний розвиток у цілому, $а$ результативність іi функціонування - один iз найважливіших параметрів соціально-економічної ефективності. При цьому визнано, що при декомпозиції завдань інтелектуально-інноваційної системи регіонів іiі необхідно розуміти як відкриту систему, яка пов’язана з іншими системами та підсистемами.

Необхідно відзначити, що інтелектуально-інноваційну систему регіонів ми розглядаємо, як сукупність взаємопов'язаних, локалізованих на певній території підсистем (формування, генерації, освоєння знань і дифузії інновацій), органів регіонального управління та інститутів, які зумовлюють активізацію інноваційного процесу та забезпечують безперервно повторювальні процеси створення, нарощення та розвитку інтелектуального потенціалу регіонів. 
Інтелектуально-інноваційну систему регіонів не слід ототожнювати 3 національною інноваційною системою, хоч вона $є$ стрижневою основою, завдяки якій здійснюється перетворюючий вплив на всю економіку країни через оптимізацію дії їі підсистем.

До переваг регіонального рівня інноваційних процесів в порівнянні 3 національним можна віднести [13]:

1) сукупну близькість великої кількості виробників різних галузей, що своєчасно пропонують спеціалізовані товари і послуги та гнучко відповідають на зміни попиту;

2) залучення регіональних суб’єктів в транснаціональні мережі викликають ефекти навчання;

3) появу локальних фондів робочої сили 3 концентрацією специфічних навиків і форм навчання;

4) культурну i iнституційну інфраструктуру, яка постійно виникає усередині і навколо промислових кластерів і яка дуже важлива для ефективної роботи єдиної локальної соціально-економічної системи;

5) розвиток довіри між регіональними економічними суб'єктами. У регіональному плані для поширення інноваційних процесів особливого значення набуває забезпечення зв'язку між реформуванням соціально-економічних відносин та іншими інституціональними перетвореннями, збалансуванням місцевих бюджетів, динамікою обсягів, структури та ефективності виробництва, а також життєвим рівнем населення.

Отже, ми вважає за доцільне впровадити нову форму просторового територіального розвитку продуктивних сил і регіональної економіки [14] форму взаємодії організаційно-економічного розвитку інтелектуально-

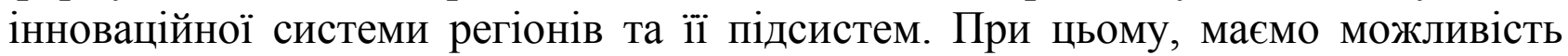
викласти базові (конститутивно-ключові) положення провадження процесів інтеграції у змісті інтеграційної концепції формування ресурснофункціонального потенціалу регіонів (ІКФ $\left.{ }_{\text {РФП}} \mathrm{P}\right)$. Інтеграція в контексті даного дослідження розглядається як об'єднання зусиль, поглиблення взаємодії та налагодження зв'язків між суб'єктами IICP, регіональними та державними органами влади, закордонними партнерами тощо. Результативність інтелектуально-інноваційної системи регіонів буде залежати від того, наскільки вона органічно вмонтована в систему суспільного життя регіону. Інституціональна структура інтелектуально-інноваційної системи характеризується взаємозалежністю підсистем, в яких ціле більше суми складових, оскільки їх єдності властивий синергізм.

На наш погляд, інтеграційну концепцію формування ресурснофункціонального потенціалу регіонів правомірно розуміти як керівну ідею, яка передбачає вибір в якості об'єкта генерування інноваційних зрушень становлення економіки знань в умовах інтеграційного вибору держави. Поряд із цим запропоновану до використання концепцію можна реалізувати завдяки виконанню наступних завдань: забезпечення сталого розвитку регіонів; відновлення конкурентних позицій; формуванню інноваційної культури тощо.

Підкреслимо, що виконання цих завдань можна досягти лише у разі: 
а) ефективного використання й активізації наявних в регіоні інтелектуальних ресурсів;

б) розроблення і реалізації стратегії розвитку інтелектуально-інноваційної системи регіонів на засадах нарощення інтелектуального капіталу та стимулювання інноваційної діяльності у реальному секторі регіональної економіки.

Ефективне функціонування та реалізація специфічних функцій інтелектуально-інноваційної системи регіонів (сформованих при поєднанні базових положень інституціонального, системного, ресурсно-функціонального та синергетичного підходів) дозволять:

1) спроектувати i запровадити у практику господарювання нову просторову форму організації та управління об'єктів системно-універсального функціонування в регіонах - інтегровану економічну систему інтелектуальноінноваційного типу;

2) забезпечити адаптацію інтелектуально-інноваційних систем регіонів до загроз і ризиків за рахунок прискорення обігу ресурсів;

3) отримати синергетичний ефект від поєднання інноваційних, інтелектуальних, інформаційних та управлінських потенціалів;

4) інтенсифікувати процеси максимальної розвиненості інноваційної та інтелектуальної сфери регіонів;

5) наповнення місцевих й загальнодержавних бюджетних надходжень шляхом поширення доступу національного виробника до потенційно широкого внутрішнього та зовнішнього ринків через оптимізацію дії науково-освітніх, фінансових, правових, управлінських і ринкових інститутів, які безпосередньо впливають на формування інноваційного середовища в регіонах.

Інтеграційна концепція формування ресурсно-функціонального потенціалу регіонів може розглядатися як процес реалізації моделі кваліметричного розрахунку i прогнозування розвитку інтелектуальноінноваційної системи регіонів за умов дотримання принципів наукової обгрунтованості інтенсифікації процесів формування, генерації, освоєння знань і дифузії інновацій задля оптимального використання інтелектуальних ресурсів, з метою забезпечення агрегованого інноваційного розвитку регіонів.

Головною метою зазначеної концепції $є$ забезпечення високого рівня ефективності розвитку інтелектуально-інноваційної системи регіонів та іiі підсистем на основі використання інтелектуального капіталу. Узагальнена блок-схема реалізації інтеграційної концепції формування ресурснофункціонального потенціалу регіонів представлена на рисунку.

Основні етапи реалізації запропонованої концепції містять наступні процедури:

a) управління використанням інтелектуального капіталу за участі суб'єктів інноваційної діяльності; 


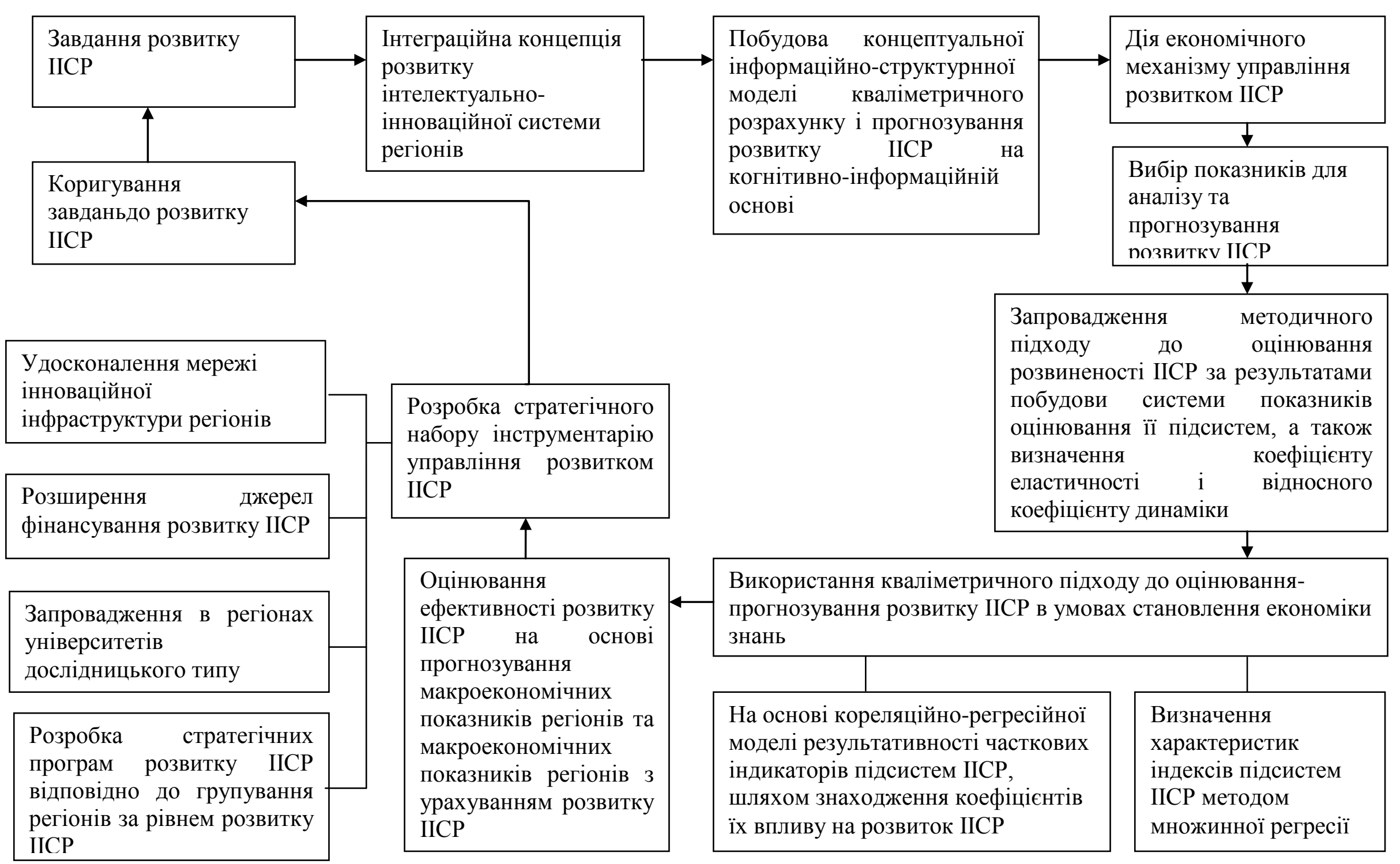

Рисунок. Узагальнена блок-схема реалізації Інтеграційної концепції формування ресурсно-функціонального потенціалу регіонів

Джерело * Розроблено та запропоновано автором 
б) налагодження взаємодії суб'єктів підсистем інтелектуальноінноваційної системи регіонів (інноваційно активних підприємств, науководослідних інститутів, ВНЗ, наукових парків, бізнес-інкубаторів та ін.).

Слід зазначити, що у залежності від розвитку інтелектуальноінноваційної системи регіонів для регіонів пропонуються різні стратегії розвитку інтелектуально-інноваційної системи регіонів, чим досягається реалізація інтеграційної концепції. Доведено, що інтелектуально-інноваційної системи регіонів має стати багаторівневою динамічною системою суспільних відносин, інституцій та організацій, основою для розвитку інтелектуального капіталу, інноваційної культури та відповідного способу мислення населення, які забезпечуватимуть прикладання зусиль до локалізації знань та дифузії інновацій.

У свою чергу реалізація інтеграційної концепції формування ресурснофункціонального потенціалу регіонів (ІКФ $\left.\Phi_{\text {РФП }} \mathrm{P}\right)$ надасть можливість для регіонів:

1) скоординувати дії всіх підсистем, що підвищить результативність інтелектуально-інноваційної системи регіонів та національної економіки в цілому;

2) підвищити культурний, освітньо-кваліфікаційний та фаховий рівень населення регіонів;

3) створити додаткові робочі місця в освітній, науковій, виробничий та інших сферах економіки регіонів;

4) вирішити регіональні екологічні і соціальні проблеми за рахунок використання нових технологій,

5) збільшити надходження до бюджетів різних рівнів за рахунок розширення обсягів виробництва інноваційної продукції на існуючих підприємствах та за рахунок створення нових підприємств;

6) підвищити синергетичний ефект від розвитку IICP, що сприятиме сталому розвитку регіонів в умовах інтеграційного вибору держави та становленню економіки знань.

Висновки. Наукова новизна даного дослідження полягає у розроблені інтеграційної концепції формування ресурсно-функціонального потенціалу регіонів, яка поєднує базові положення інституціонального, системного, ресурсно-функціонального та синергетичного підходів, $\epsilon$ узагальненим відображенням логіки дослідження, для: а) розроблення методики оцінки розвитку інтелектуально-інноваційної системи регіонів, б) здійснення прогнозування розвитку інтелектуально-інноваційної системи регіонів та соціально-економічних показників регіонів, в) вибору стратегії розвитку регіонів за використання практичного інструментарію та відтворенням можливих шляхів розвитку інтелектуально-інноваційної системи регіонів в умовах інтеграційного вибору держави. Таким чином, основні засади 
пропонованої до використання концепції - це реалізація процесів формування, генерації, освоєння знання та дифузії інновацій, забезпечення ефективності розвитку інтелектуально-інноваційної системи регіонів в умовах інтеграційного вибору держави, що надасть можливість становленню економіки знань. Головною метою впровадження концепції є побудова дієвої стратегії розвитку регіонів, використання результатів науково-інноваційної діяльності для їх сталого розвитку.

Перспективи подальших наукових розробок за даним напрямом дослідження полягають у поглиблені вивчення проблем становлення економіки знань в Україні на сучасному етапі розвитку продуктивних сил та регіональної економіки за умов розроблення дієвих стратегій розвитку регіонів.

Теоретичне та практичне значення результатів дослідження полягає у тому, що запропонована до використання інтеграційна концепція формування ресурсно-функціонального потенціалу регіонів дозволить обгрунтувати напрями діяльності суб'єктів інтелектуально-інноваційної системи регіонів, котрі зумовлюють інтенсифікацію процесів формування, генерації, освоєння знань та дифузії інновацій на засадах об'єктивної ідентифікації. У межах цієї концепції можна використовувати стратегічне управління та розробити методологічний підхід до оцінювання розвитку інтелектуально-інноваційної системи регіонів та здійснювати прогнозування розвитку інтелектуальноінноваційної системи регіонів та їі вплив на соціально-економічні показники регіонів.

1. Активізація інноваційної діяльності: організаційно-правове та соціальне забезпечення: Монографія [Текст] / О. I. Амоша, В. П. Антонюк, А. I. Землянкін та ін. / НАН України, Інститут економіки промисловості. - Донецьк: Інститут економіки промисловості, 2007. - $328 \mathrm{c.}$

2. Алимов О. М.. Стратегічний потенціал продуктивних сил регіонів України: Монографія / [Алимов О. М., Бандур С. І., Дейнеко JI. В., Микитенко В. В. та ін.] / За ред. д.е.н., проф. Б. М. Данилишина. - К.: РВПС України НАН України. 2009. - 424 с.

3. Бережная В. И. Региональные проблемы инновационного развития: моногр. / В. И. Бережная, Е. А. Михуринская, Е. А. Смирнова. - Симферополь: ИТ «АРИАЛ», 2012. $-226 \mathrm{c}$.

4. Бубенко П. Т. Регіональні аспекти інноваційного розвитку: Монографія [Текст] / П. T. Бубенко. - Х.: НТУ «ХПІ», 2002. - 316 с.

5. Василенко В. Н., Медведь В. Ю., Савельєва Т. М. Экономическое развитие регионов: сходство и различие: Монография [Текст] / В. Н. Василенко, В. Ю. Медведь, Т. М. Савельєва. - Донецк: Юго-Восток, 2010. - 219 с.

6. Геєць В. М. Інноваційні перспективи України: Монографія [Текст] / В. М. Геєuь, В. П. Семиноженко. - Харків: Константа, 2006. - 272 с. 
7. Герасимчук 3. В. Організаційно-економічний механізм становлення інноваційного потенціалу регіону: Монографія [Текст] / 3. В. Герамсимчук, Н. С. Куцай. - Луцьк: РВВ ЛНТУ, 2011. - $216 \mathrm{c.}$

8. Дуленко А. Л. Инновационному процессу - новое экономическое мышление. Соціально-економічний розвиток регіонів України: проблеми науки та практика [Текст] / А. Л. Дуленко, П. Т. Бубенко, А. Д. Кашпур / Монографія. - Харків: ВД «ІНЖЕК», 2007. - $404 \mathrm{c}$.

9. Кондрашихін А. Б. Координатні виміри інноваційного простору регіону: наук. монограф. [Текст] / А. Б. Кондрашихін; М-во трансп. та зв’язку України, Держ. економ.-технол. ун-т трансп. - К.: Держ. економ.-технол. ун-т трансп. $-2010 .-200$ с.

10. Регіони України: проблеми та пріоритети соціально-економічного розвитку: Монографія [Текст] / За ред. 3. С. Варналія. - К.: Знання України, 2005. - 498 с.

11. Романюк C. A. Політика регіонального розвитку в Україні: сучасний стан і нові можливості: Регіональні дослідження: Монографія [Текст] / С. А. Романюк. - К.: УАДУ, 2001. - $112 \mathrm{c.}$

12. Соловйов В. П. Інноваційний розвиток регіонів: питання теорії та практики: Монографія [Текст] / В. П. Соловйов, Г. І. Кореняко, М. В. Головатюк. - К.: Фенікс, 2008. $-224 \mathrm{c}$

13. Тульчинська C. O. Інтелектуально-інноваційна модернізація економіки України: теоретико-методологічні аспекти: Монографія [Текст] / C. О. Тульчинська. - К.: НТУУ «КПІ», 2009. - 488 с.

14. Тульчинська С. О. Органічність функціонування інтелектуально-інноваційної системи регіонів: Монографія [Текст] / C. О. Тульчинська. - Херсон: Ви-во «ПП Вишемирський В.С.», 2012. - 400 с.

15. Україна у вимірі економіки знань [Текст] / [за ред. акад. НАН України В. М. Гейuя]. К.: Основа, 2006. - 592 с.

16. Управління інноваційними процесами в регіонах: Монографія[Текст] / [за ред. М. А. Козоріз і Т. С. Смовженко]. - Львів: ЛБІ НБУ, 2006. - 263 с.

17. Шичков A. Н. Экономика и менеджмент инновационных процессов в регионе: Монография [Текст] / A. Н. Шичков. - М.: ИД «Финансы и кредит», 2008. - 360 с. 